\title{
Protonation effects on the chemical shifts of Schiff bases derived from 3-hydroxypyridin-4-carboxaldehyde
}

\author{
Dionisia Sanz,, ${ }^{\text {a, }}$ Almudena Perona, ${ }^{\text {a, }}$ Rosa M. Claramunt, ${ }^{\text {a }}$ Elena Pinilla, \\ M. Rosario Torres, ${ }^{b}$ and José Elguero ${ }^{c}$ \\ a Departamento de Química Orgánica y Bio-Orgánica, Facultad de Ciencias, UNED, Senda del

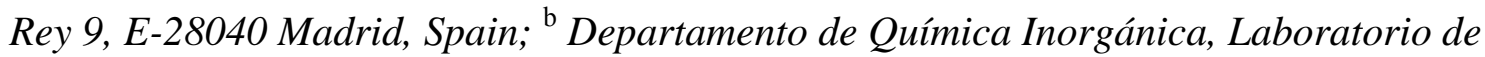 \\ Difracción de Rayos-X, Facultad de Ciencias Químicas, UCM, E-28040 Madrid, Spain; ${ }^{c}$ \\ Instituto de Química Médica, CSIC, Juan de la Cierva 3, E-28006 Madrid, Spain \\ E-mail: dsanz@ccia.uned.es; almuperona@gmail.com
}

\section{Dedicated to Prof. Benito Alcaide on the occasion of his 60th anniversary}

\begin{abstract}
The behavior of Schiff bases derived from 3-hydroxypyridin-4-carboxaldehyde and two $N$ aminoheterocycles in acid media is described. ${ }^{1} \mathrm{H},{ }^{13} \mathrm{C},{ }^{15} \mathrm{~N}$ NMR chemical shifts establish the different protonation sites and their influence on the hydroxyimino/oxoenamino tautomerism.
\end{abstract}

Keywords: Schiff bases, $N$-aminopyrazole, $N$-aminobenzimidazole, protonation, NMR, X-ray, B3LYP/6-31G** calculations

\section{Introduction}

Pyridoxal is one of the three natural forms of vitamin B6. All of these forms are converted in the human body into a single biologically active form, pyridoxal-5'-phosphate (PLP). Green plants are a natural source of pyridoxal, and its deficiency in the human body can lead to serious complications such as epilepsy and seizures. ${ }^{1,2}$ The mechanism and stereochemistry of the PLPdependent enzymic reactions have been studied in great detail and many intermediates have been identified. ${ }^{3,4,5}$ Some of these intermediates correspond to the formation of Schiff bases with the substrates. In the absence of the substrate, the formyl group at position 4 of the pyridine is forming a Schiff base with the $\varepsilon$-amino group of a specific residue of lysine in the active center. ${ }^{6}$ When an amino acid reaches the active center, it displaces the lysine and forms a new Schiff base, usually in the form of a pyridinium ion. From that step, the transaminations, decarboxylations, deaminations and aldolic cleavages take place. ${ }^{7}$ In recent times, Toney and Limbach have published a series of seminal papers on the mechanisms involving PLP. ${ }^{8,9,10,11}$ 
We have devoted a series of five papers to the structure of the Schiff bases (1) of 3hydroxypyridin-4-carboxaldehyde (2). ${ }^{1,2,3,4,5}$ In these papers we have discussed in detail the relationship of these Schiff bases with pyridoxal (PL) and its phosphate, pyridoxal-5'-phosphate (PLP). One of the aspects related to the action mode of PLP is the protonation of the pyridine ring; in the case of model compound $\mathbf{1}$, the formation of $\mathbf{3}$.

We have carried out this study on the Schiff bases of 2 with the following two amines: 1aminopyrazole (a) and 1-aminobenzimidazole (b). In the case of the Schiff base of 1aminobenzimidazole (1b), its structure has been determined by X-ray crystallography.<smiles>[R]N=Cc1ccncc1O</smiles>

1<smiles>O=Cc1ccncc1O</smiles>

2<smiles>[R]N=Cc1cc[nH+]cc1O</smiles>

3

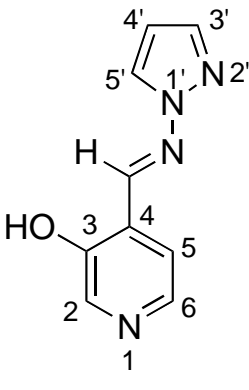

$1 \mathrm{a}$

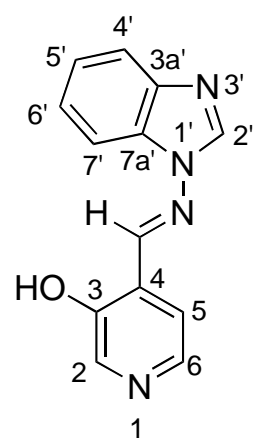

1b

Scheme 1. Compounds studied in this work.

\section{Results and Discussion}

\section{The X-ray structure of 4-(E)-[1H-benzimidazol-1-ylimino)methyl]pyridin-3-ol (1b)}

We tried to obtain suitable crystals to determine the X-ray molecular structure of $\mathbf{1 a}$ and $\mathbf{1 b}$ but only in the case of $\mathbf{1 b}$ and only when crystallized in water we succeeded. The molecular structure of compound 1b showing the atomic numbering is depicted in Figure 1 and selected distances and angles including the hydrogen bonds are listed in Table 1.

The asymmetric unit comprises a molecule linked by strong hydrogen bonding to a water molecule. The torsion angles values prove the planarity of the molecule. 


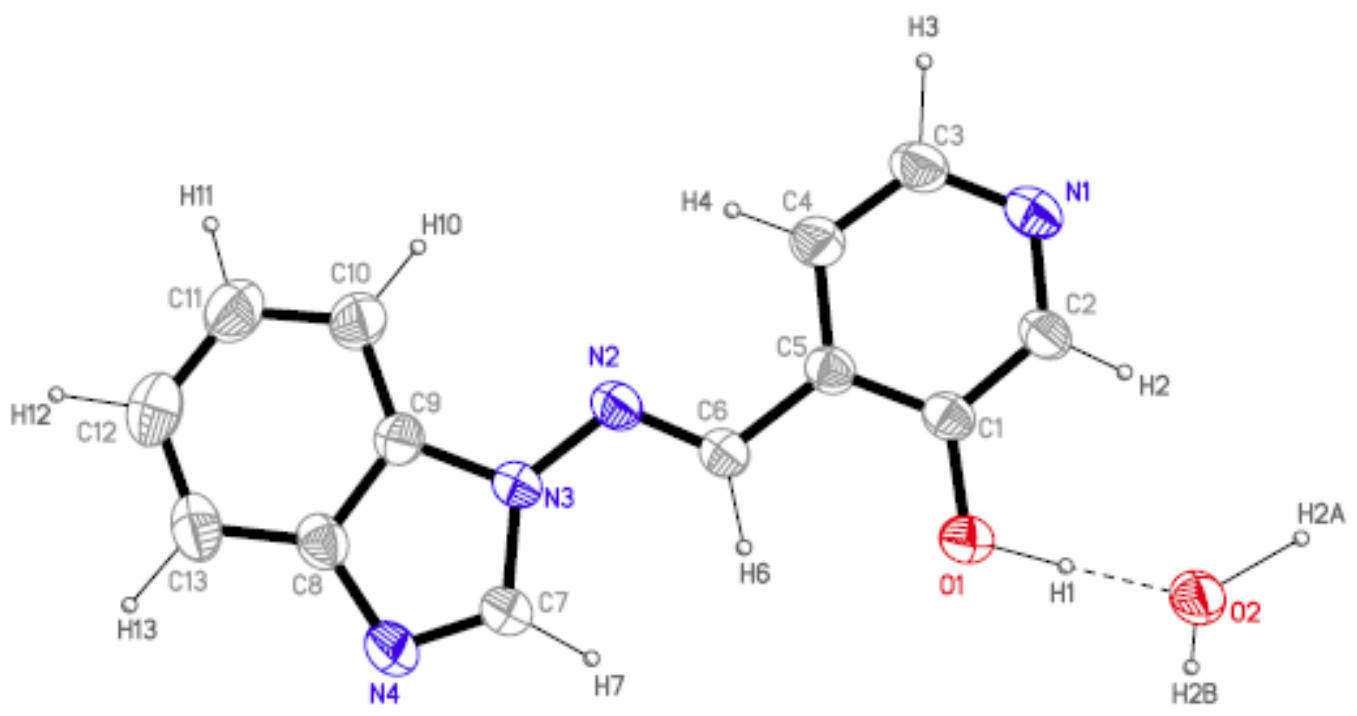

Figure 1. The X-ray molecular structure of compound $\mathbf{1 b} \cdot \mathrm{H}_{2} \mathrm{O}$ (ORTEP plot, $40 \%$ probability for the ellipsoids).

The two hydrogen atoms of the water molecules are responsible for the formation of large waved layers parallel to (101) (Figure 2).

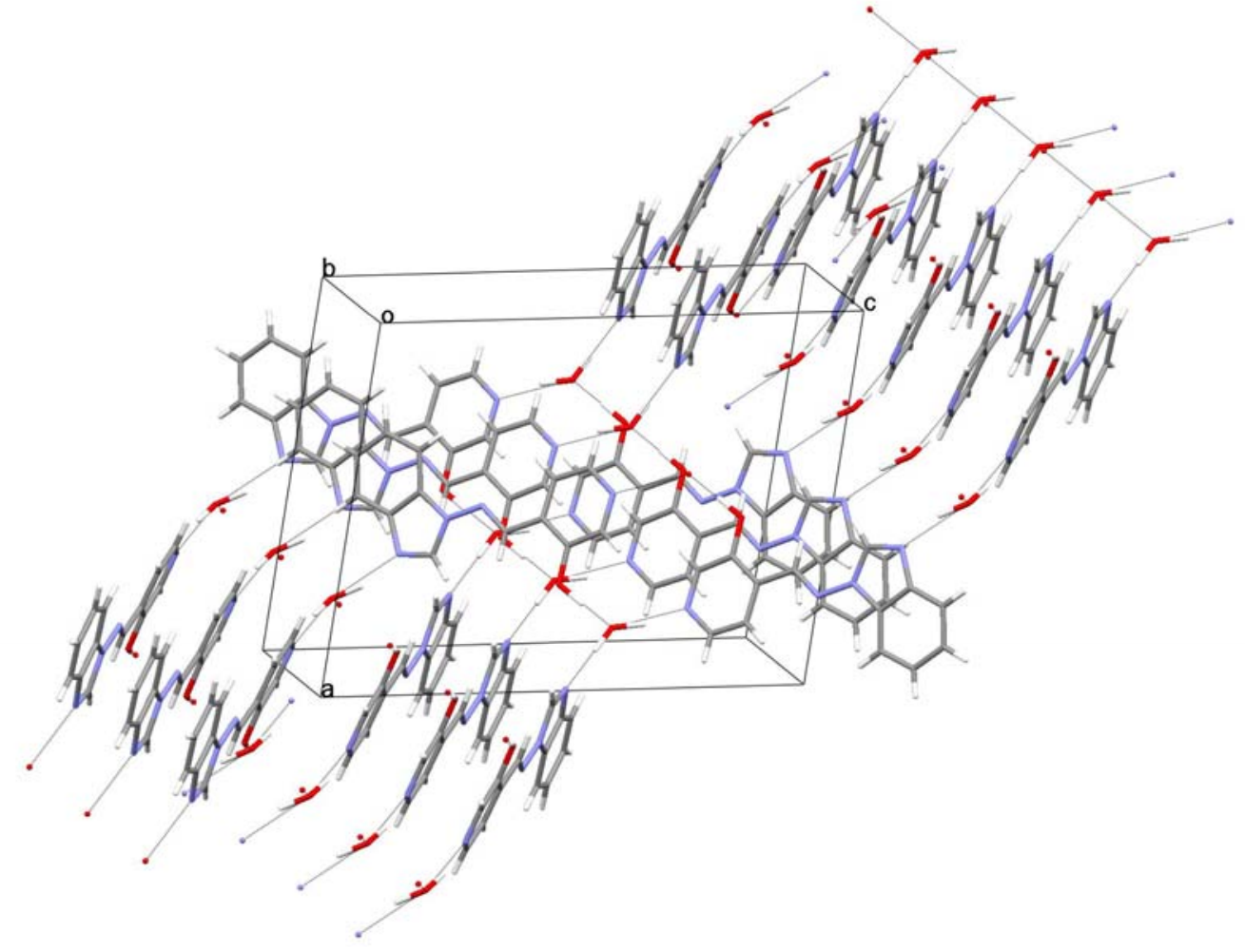

Figure 2. 2D network of $\mathbf{1 b}$ showing the layers parallel to (101) due to intermolecular hydrogen bonds. 
Table 1. Selected bond lengths $[\AA]$ and angles $\left[^{\circ}\right]$ including hydrogen bonds for $\mathbf{1 b}$

\begin{tabular}{|c|c|c|c|}
\hline N3-N2 & $1.384(3)$ & N3-N2-C6 & $118.4(2)$ \\
\hline N2-C6 & $1.276(3)$ & N2-C6-C5 & $119.0(2)$ \\
\hline $\mathrm{C} 5-\mathrm{C} 6$ & $1.458(3)$ & $\mathrm{C} 6-\mathrm{C} 5-\mathrm{C} 1$ & $120.9(2)$ \\
\hline $\mathrm{C} 1-\mathrm{O} 1$ & $1.353(3)$ & $\mathrm{C} 2-\mathrm{C} 1-\mathrm{O} 1$ & $121.7(2)$ \\
\hline N1-C2 & $1.330(3)$ & $\mathrm{C} 7-\mathrm{N} 3-\mathrm{N} 2$ & $132.6(2)$ \\
\hline N1-C3 & $1.341(3)$ & C7-N3-C9 & $106.8(2)$ \\
\hline N3-C7 & $1.365(3)$ & N3-C7-N4 & $112.9(2)$ \\
\hline N3-C9 & $1.380(3)$ & C7-N4-C8 & $105.4(2)$ \\
\hline C9-C8 & $1.391(3)$ & N3-C9-C8 & $105.3(3)$ \\
\hline $\mathrm{C} 8-\mathrm{N} 4$ & $1.394(3)$ & & \\
\hline N4-C7 & $1.299(3)$ & & \\
\hline $\mathrm{O} 1-\mathrm{H} 1$ & 1.12 & $\mathrm{C} 1-\mathrm{O} 1-\mathrm{H} 1$ & 107.7 \\
\hline $\mathrm{O} 1 \cdots \mathrm{O} 2$ & $2.617(2)$ & $\mathrm{O} 1-\mathrm{H} 1 \ldots \mathrm{O} 2$ & 177.2 \\
\hline $\mathrm{O} 2 \cdots \mathrm{H} 1$ & 1.50 & $\mathrm{O} 2-\mathrm{H} 2 \mathrm{~A} \ldots \mathrm{N} 1^{\mathrm{a}}$ & 167.2 \\
\hline $\mathrm{O} 2-\mathrm{H} 2 \mathrm{~A}$ & 1.12 & $\mathrm{O} 2-\mathrm{H} 2 \mathrm{~B} \ldots \mathrm{N} 4^{\mathrm{b}}$ & 160.8 \\
\hline $\mathrm{O} 2-\mathrm{H} 2 \mathrm{~B}$ & 1.12 & & \\
\hline $\mathrm{O} 2 \cdots 1^{a}$ & $2.836(3)$ & & \\
\hline $\mathrm{O} 2 \cdots \mathrm{N} 4^{\mathrm{b}}$ & $2.806(3)$ & & \\
\hline $\mathrm{H} 2 \mathrm{~A}^{\cdots \cdots} \mathrm{N} 1^{\mathrm{a}}$ & 1.73 & & \\
\hline $\mathrm{H} 2 \mathrm{~B} \ldots \mathrm{N} 4^{\mathrm{b}}$ & 1.72 & & \\
\hline
\end{tabular}

The structure corresponds to the imino tautomer, which is the most stable in the case of the Schiff base derived from aniline, ${ }^{12}$ but here we observe an intermolecular hydrogen bond involving a water molecule and not an intramolecular one (IMHB) with the imino nitrogen atom.

\section{NMR results. Protonation site of $1 \mathrm{a}$ and $1 \mathrm{~b}$}

Besides salt 3, protonated on the pyridine ring, both Schiff bases studied in this paper could be protonated either on the imino nitrogen atom to yield $\mathbf{4 a}$ and $\mathbf{4 b}$ or on the heterocyclic nitrogen yielding $\mathbf{5 a}$ and $\mathbf{5 b}$ (Scheme 2). 
<smiles></smiles>

$4 a$

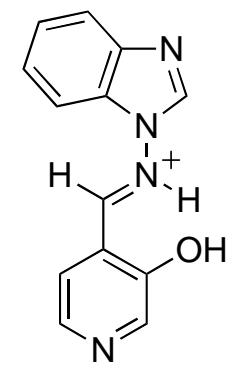

4b<smiles></smiles>

$5 \mathbf{a}$<smiles>Oc1cnccc1/C=N/n1c[nH+]c2ccccc21</smiles>

$5 b$

Scheme 2. Possible conjugated acids.

We have compared the chemical shifts and some coupling constants of the neutral species $\mathbf{1}$ with those of the protonated compounds. For the protonated compounds two strategies have been used: recording the spectra of $\mathbf{1}$ in trifluoroacetic acid (TFAA) or preparing the tetrafluoroborate (TFB) of $\mathbf{1}$ and recording its spectrum in a neutral solvent.

\section{${ }^{1} \mathrm{H}$ NMR results}

In the previous papers we have reported the NMR data of $\mathbf{1 a},{ }^{13} \mathbf{1} \mathbf{b},{ }^{14}$ and the site of protonation of the compounds 1 where $\mathrm{R}$ is a phenyl ring. ${ }^{15}$ The main conclusion of the last study was that the keto/enol equilibrium which is strongly shifted to the enol form $\mathbf{1 0 H}$ in the neutral molecule (Scheme 3) is about 50/50 30H/3CO (depending on R) in the protonated form. Also the protonation shifts, $\Delta \delta=\delta$ (protonated) $-\delta$ (neutral) were determined for the different nuclei. The results are reported in Tables 2 (pyrazole) and 3 (benzimidazole).<smiles></smiles>

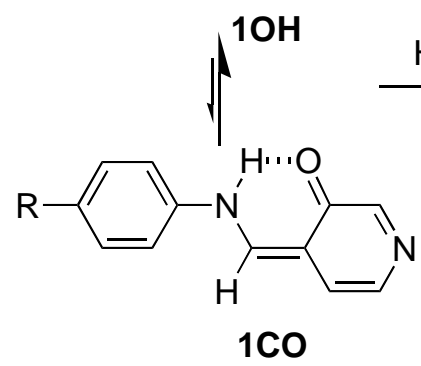<smiles></smiles>

$30 \mathrm{H}$

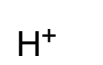<smiles>C1=CC=C1</smiles><smiles>[R]c1ccc(N2[CH]OC(=O)C(=C[CH])C=C2)cc1</smiles>

Scheme 3. Effect of the protonation on the tautomerism of Schiff bases 1.

In the previous works we have determined the effects produced by protonation on Schiff bases of type $\mathbf{1}^{15}$ and also on $\mathrm{N}$-aminoazoles, amongst them $\mathrm{N}$-aminopyrazole and $\mathrm{N}$ - 
aminobenzimidazole (Scheme 4). ${ }^{6}$ Most of these values resulted from the comparison of $\mathrm{CF}_{3} \mathrm{CO}_{2} \mathrm{H}$ with $\mathrm{CDCl}_{3}$ but some ( $\Delta^{1} J$ of 1 -aminobenzimidazole) correspond to $\mathrm{CF}_{3} \mathrm{CO}_{2} \mathrm{H} / \mathrm{DMSO}-d_{6}$ differences.

Table 2. Chemical shifts ( $\delta$ in ppm) and coupling constants $(\mathrm{J}$ in $\mathrm{Hz})$ in $\mathrm{CF}_{3} \mathrm{CO}_{2} \mathrm{H}$, protonation effects $\left(\Delta \delta=\delta_{\mathrm{H}^{+}}-\delta_{\mathrm{CDCl}}\right.$ in ppm) and $\left(\Delta^{1} J=J_{\mathrm{H}^{+}}-J_{\mathrm{CDCl} 3}\right)$ for $\mathbf{1 a}$.

\begin{tabular}{lllllllllllll}
\hline Atom & 1 & 2 & 3 & 4 & 5 & 6 & $\mathrm{CH}=\mathrm{N}$ & $1^{\prime}$ & $2^{\prime}$ & $3^{\prime}$ & $4^{\prime}$ & $5^{\prime}$ \\
\hline${ }^{1} \mathrm{H}$ & ---- & 8.54 & ---- & ---- & $8.24^{\mathrm{a}}$ & $8.33^{\mathrm{a}}$ & 9.30 & ---- & ---- & 8.03 & 6.75 & 8.21 \\
$\Delta \delta$ & & 0.04 & & & 0.95 & 0.06 & 0.07 & & & 0.41 & 0.30 & 0.50 \\
${ }^{13} \mathrm{C}$ & ---- & 131.3 & 155.6 & 132.1 & 127.1 & 131.7 & 147.7 & ---- & ---- & 138.9 & 108.6 & 129.3 \\
$\Delta \delta$ & & -9.5 & 2.8 & 9.9 & 3.1 & -9.5 & -2.6 & & & -0.1 & 1.1 & 0.3 \\
${ }^{1} J$ & --- & 193.1 & ---- & ---- & 175.1 & 199.3 & 178.4 & ---- & ---- & 195.9 & 187.6 & 198.3 \\
$\Delta^{1} J$ & & 13.2 & & & 14.4 & 16.9 & 6.3 & & & 7.6 & 7.8 & 5.9 \\
${ }^{15} \mathrm{~N}$ & -181.9 & ---- & ---- & ---- & ---- & ---- & -66.7 & -147.3 & -137.0 & & & \\
$\Delta \delta$ & -124.4 & & & & & & 11.5 & -5.6 & -39.2 & & & \\
\hline
\end{tabular}

${ }^{\mathrm{a} 3} J_{\text {ortho }}=5.5 \mathrm{~Hz}$

Table 3. Chemical shifts ( $\delta$ in ppm) and coupling constants $(\mathrm{J}$ in $\mathrm{Hz})$ in $\mathrm{CF}_{3} \mathrm{CO}_{2} \mathrm{H}$, protonation effects $\left(\Delta \delta=\delta_{\mathrm{H}^{+}}-\delta_{\mathrm{CDCl}}\right.$ in ppm) and $\left(\Delta^{1} J=J_{\mathrm{H}^{+}}-J_{\mathrm{DMSO}-\mathrm{d} 6}\right)$ for $\mathbf{1 b}$ and of the tetrafluoroborate salt in DMSO- $d_{6}$ and in the solid state (CPMAS)

\begin{tabular}{|c|c|c|c|c|c|c|c|c|c|}
\hline & \multirow{2}{*}{\multicolumn{3}{|c|}{$\frac{\text { Base }}{\text { TFAA }}$}} & \multicolumn{6}{|c|}{ Tetrafluoroborate } \\
\hline & & & & & & DMSO & & & CPMAS \\
\hline & $\delta$ & $\Delta \delta$ & ${ }^{1} J^{\mathrm{a}}$ & $\Delta^{1} J^{\mathrm{a}}$ & $\delta$ & $\Delta \delta$ & ${ }^{1} J^{\mathrm{a}}$ & $\Delta^{1} J^{\mathrm{a}}$ & $\delta$ \\
\hline $\mathrm{H} 2$ & 8.67 & 0.09 & ---- & & 8.49 & -0.09 & ---- & & \\
\hline H5 & $8.50^{\mathrm{b}}$ & 1.19 & --- & & $8.43^{\mathrm{c}}$ & 1.12 & ---- & & \\
\hline H6 & $8.42^{\mathrm{b}}$ & 0.08 & --- & & $8.45^{\mathrm{c}}$ & 0.11 & ---- & & \\
\hline $\mathrm{CH}=\mathrm{N}$ & 9.61 & 0.71 & ---- & & 9.43 & 0.53 & ---- & & \\
\hline $\mathrm{H} 2^{\prime}$ & 9.70 & 1.29 & ---- & & 9.82 & 1.41 & ---- & & \\
\hline H4' & 7.86 & 0.00 & ---- & & 7.85 & -0.01 & ---- & & \\
\hline $\mathrm{H} 5$ & 7.73 & 0.32 & ---- & & 7.53 & 0.12 & ---- & & \\
\hline H6' & 7.76 & 0.30 & ---- & & 7.59 & 0.13 & ---- & & \\
\hline $\mathrm{H} 7$, & 7.99 & 0.30 & ---- & & 8.01 & 0.32 & ---- & & \\
\hline $\mathrm{C} 2$ & 131.8 & -9.5 & 193.0 & 13.8 & 133.3 & -8.0 & 188.5 & 9.3 & 131.6 \\
\hline $\mathrm{C} 3$ & 155.7 & 2.8 & ---- & & 154.8 & 1.9 & ---- & & 155.3 \\
\hline $\mathrm{C} 4$ & 132.2 & 10.3 & ---- & & 132.6 & 10.7 & ---- & & 134.8 \\
\hline $\mathrm{C} 5$ & 126.3 & 2.8 & 176.2 & 14.3 & 122.9 & -0.6 & 172.8 & 10.9 & 126.3 \\
\hline C6 & 132.2 & -9.2 & 197.7 & 16.5 & 134.2 & -7.2 & 192.6 & 11.4 & 131.6 \\
\hline $\mathrm{CH}=\mathrm{N}$ & 155.3 & 3.2 & 177.7 & 8.1 & 148.5 & -3.6 & 175.5 & 5.9 & 148.2 \\
\hline $\mathrm{C} 2$ ' & 133.4 & -2.5 & 223.9 & 9.9 & 136.5 & 0.6 & 219.3 & 5.3 & 133.7 \\
\hline
\end{tabular}


Table 3. Continued

\begin{tabular}{|c|c|c|c|c|c|c|c|c|c|}
\hline & \multirow{2}{*}{\multicolumn{3}{|c|}{$\begin{array}{c}\text { Base } \\
\text { TFAA }\end{array}$}} & \multicolumn{6}{|c|}{ Tetrafluoroborate } \\
\hline & & & & & & DMSO & & & CPMAS \\
\hline & $\delta$ & $\Delta \delta$ & ${ }^{1} J^{\mathrm{a}}$ & $\Delta^{1} J^{\mathrm{a}}$ & $\delta$ & $\Delta \delta$ & ${ }^{1} J^{\mathrm{a}}$ & $\Delta^{1} J^{\mathrm{a}}$ & $\delta$ \\
\hline C3a' & 128.7 & -13.9 & ---- & & 135.7 & -6.9 & ---- & & 133.7 \\
\hline $\mathrm{C} 4$, & 111.4 & -7.0 & 170.2 & 8.4 & 117.8 & -3.6 & 165.5 & 3.7 & 116.3 \\
\hline $\mathrm{C} 5$, & 128.5 & 4.3 & 165.2 & 4.8 & 125.5 & 1.1 & 162.0 & 1.6 & 128.4 \\
\hline C6' & 128.6 & 3.5 & 165.2 & 4.2 & 125.9 & 0.8 & 163.0 & 2.0 & 128.4 \\
\hline $\mathrm{C} 7{ }^{\prime}$ & 111.6 & 1.4 & 165.6 & 0.6 & 111.9 & 1.7 & 168.5 & 3.5 & 112.2 \\
\hline $\mathrm{C} 7 \mathrm{a}^{\prime}$ & 128.1 & -2.9 & ---- & & 131.0 & 0.0 & ---- & & 128.8 \\
\hline N1 & -178.5 & -125.3 & ---- & & -147.7 & -94.5 & ---- & & -178.7 \\
\hline $\mathrm{CH}=\mathrm{N}$ & -66.2 & 4.1 & ---- & & -64.6 & 5.7 & ---- & & -67.5 \\
\hline N1' & -180.5 & 0.7 & ---- & & -179.4 & 1.8 & ---- & & -183.4 \\
\hline N3' & -225.4 & -91.0 & --- & & -178.4 & -44.0 & --- & & -221.3 \\
\hline
\end{tabular}

${ }^{\mathrm{a}}$ data for neutral species $1 \mathbf{b}$ in DMSO- $d_{6} ;{ }^{\mathrm{b}}{ }^{3} J_{\text {ortho }}=6.0 \mathrm{~Hz} ;{ }^{\mathrm{c} 3} J_{\text {ortho }}=5.8 \mathrm{~Hz}$

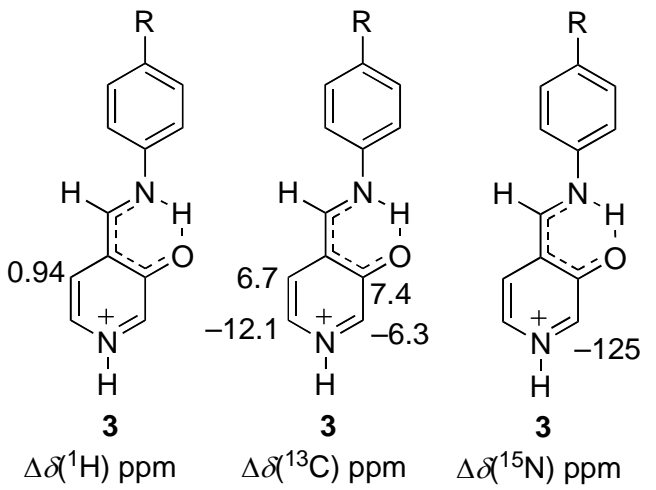
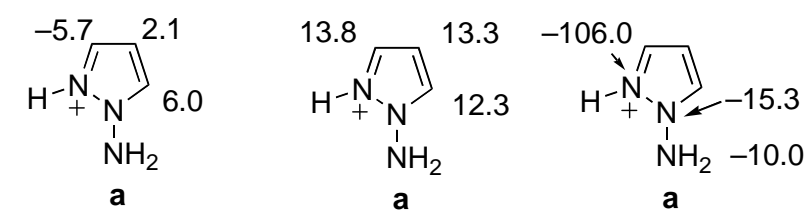

$\Delta \delta\left({ }^{13} \mathrm{C}\right) \mathrm{ppm}$

$\Delta^{1} \mathrm{~J}\left({ }^{1} \mathrm{H}^{13} \mathrm{C}\right) \mathrm{Hz}$

$\Delta \delta\left({ }^{15} \mathrm{~N}\right) \mathrm{ppm}$
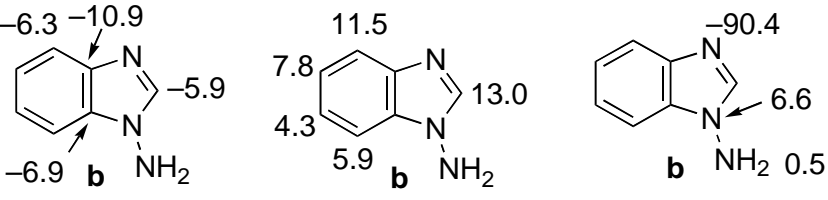

$\Delta \delta\left({ }^{13} \mathrm{C}\right) \mathrm{ppm}$

$\Delta^{1} \mathrm{~J}\left({ }^{1} \mathrm{H}^{-13} \mathrm{C}\right) \mathrm{Hz}$

$\Delta \delta\left({ }^{15} \mathrm{~N}\right) \mathrm{ppm}$

Scheme 4. Protonation effects from the literature. ${ }^{15,17}$

If we compare the protonation effects of Tables 2 and 3 with those of the fragments of Scheme 4 we can reach the following conclusions:

1. There is no indication that protonation occurs on the imine nitrogen to afford $\mathbf{4 a}$ and $\mathbf{4 b}$.

2. The chemical shifts of the imino carbon (147.7 ppm 1a and $155.3 \mathrm{ppm} \mathrm{1b})$ indicate that these cations exist only, or predominantly, in the $\mathrm{OH}$ tautomeric structure (see Scheme 3) by comparison with $\mathbf{3 O H}$ cations (153-161 ppm). ${ }^{15}$

3. In the case of $\mathbf{1 a}$ dissolved in $\mathrm{CF}_{3} \mathrm{CO}_{2} \mathrm{H}$ the pyridine ring is fully protonated (compare -124.4

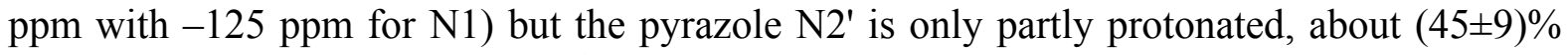
(compare the ${ }^{1} J_{\mathrm{CH}}$ and also the ${ }^{15} \mathrm{~N}$ chemical shift of $\mathrm{N} 2$ ', Scheme 4). For instance, the average effect on ${ }^{1} J_{\mathrm{CH}}$ in 1-aminopyrazole is $\Delta^{1} J\left({ }^{1} \mathrm{H}-{ }^{13} \mathrm{C}\right)=13.1 \mathrm{~Hz}$ while in 1a is $7.1 \mathrm{~Hz}$, 
which represents $54 \%$ of protonation. The effect on $\mathrm{N} 2, \Delta \delta\left({ }^{15} \mathrm{~N}\right)$, is $-39.2 \mathrm{ppm}$ that compared to the effect on 1-aminopyrazole, $-106.0 \mathrm{ppm}$ (Scheme 4), led to $37 \%$.

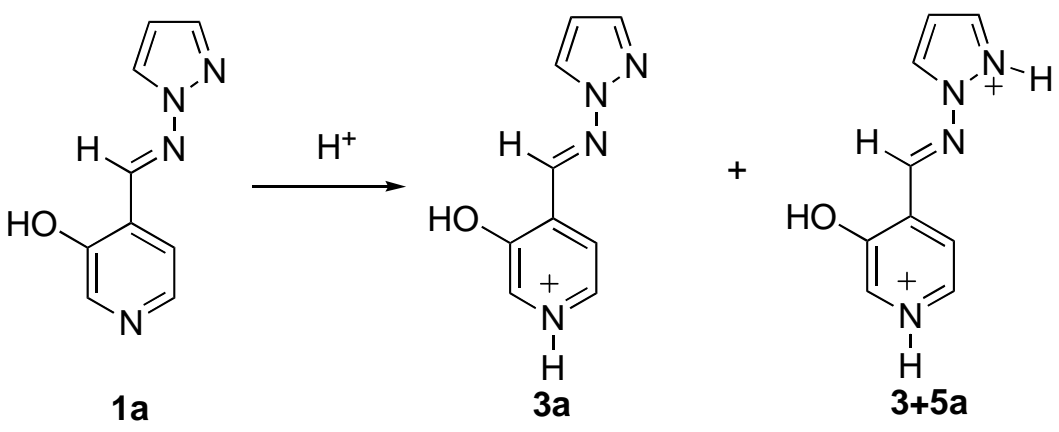

Scheme 5. Structure of the monocation $3 a$ and dication $3+5 a$.

4. In the case of $\mathbf{1 b}$ dissolved in $\mathrm{CF}_{3} \mathrm{CO}_{2} \mathrm{H}$ both the pyridine and the benzimidazole (N3) rings are fully protonated (compare change of 1.19 to $0.94 \mathrm{ppm}$ for $\mathrm{H} 5,-125.3$ to $-125 \mathrm{ppm}$ for N1 and -91.0 to $-90.4 \mathrm{ppm}$ for N3'), thus the dication has the structure $\mathbf{3}+5 \mathbf{b}$ (Scheme 6 ). When the tetrafluoroborate salt of $\mathbf{1 b}$ is dissolved in DMSO- $d_{6}$ this results in some dissociation of the dication $\mathbf{3 + 5 b}$ into monocations $\mathbf{3 b}$ and $\mathbf{5 b}$. This is particularly clear in ${ }^{15} \mathrm{~N} N \mathrm{NM}$ where the effects observed in $\mathrm{CF}_{3} \mathrm{CO}_{2} \mathrm{H}$ decrease from $-125.3(\mathrm{~N} 1)$ and $-91.0\left(\mathrm{~N} 3{ }^{\prime}\right)$ to $-94.5(\mathrm{~N} 1)$ and -44.0 ppm $\left(\mathrm{N} 3^{\prime}\right)$ in DMSO- $d_{6}$.

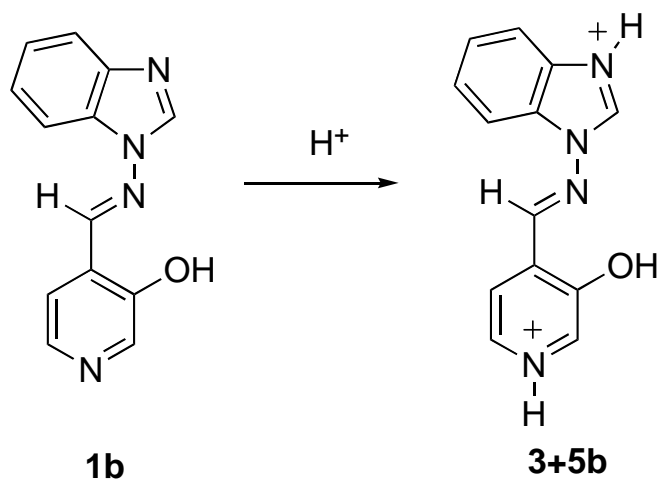

Scheme 6. Structure of the dication $3+5 \mathbf{b}$.

5. In the solid state, the tetrafluoroborate shows the same ${ }^{15} \mathrm{~N}$ chemical shifts of the four nitrogen atoms as the base in $\mathrm{CF}_{3} \mathrm{CO}_{2} \mathrm{H}$, proving that it is a bis-tetra-fluoroborate of $\mathbf{1 b}$. 


\section{Theoretical calculations}

We have calculated at the B3LYP/6-31G** level including the ZPE correction the mono- and diprotonated cations depicted in Scheme 7.

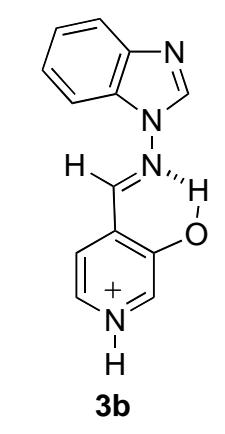

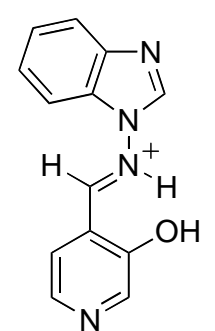

4b

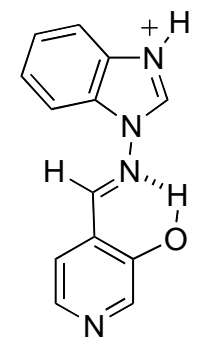

$5 b$

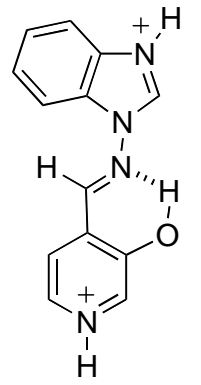

$3+5 b$

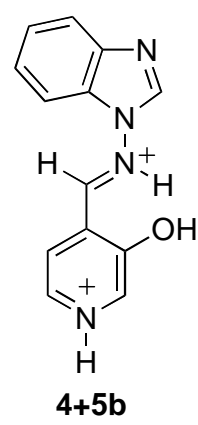

$E_{\text {rel }}=0.0 \mathrm{~kJ} \mathrm{~mol}^{-1}$

$\mathrm{E}_{\mathrm{rel}}=51.0 \mathrm{~kJ} \mathrm{~mol}^{-1}$

Scheme 7. Monocations and dications resulting from protonation of $\mathbf{1 b}$.

Although the monocation protonated on the pyridine ring $\mathbf{3 b}$ is more stable than that protonated on the benzimidazole, the energy difference is small and both should be formed in the first protonation step (cation $\mathbf{4 b}$ is not a minimum and was not observed experimentally). The second protonation should lead to $\mathbf{3}+\mathbf{5 b}$ which is much more stable than the $\mathbf{4}+\mathbf{5 b}$ salt, this is also in agreement with the experimental results.

In conclusion, the salts formed by protonation of the Schiff bases of 3-hydroxypyridin-4carboxaldehyde derived from $\mathrm{N}$-aminoazoles are dications with one proton on the pyridine ring and the other one on the azole (N2' in pyrazole and N3' in benzimidazole). Always, the tautomer present is the $\mathrm{OH}$ one (hydroxyimino).

\section{Experimental Section}

General Procedures. The synthesis and characterization of the Schiff bases $\mathbf{1 a}$ and $\mathbf{1 b}$ is reported in references 13 and 14 . 4-(E)-[(1H-benzimidazol-1-ylimino)methyl $] 3-$ hydroxypyridinium bis-tetrafluoroborate $\mathbf{1 b} \cdot\left(\mathrm{BF}_{4} \mathrm{H}\right)_{2}$. A $54 \%$ solution of tetrafluoroboric acid in diethyl ether in excess and the Schiff base in the same solvent were mixed with continuous stirring. A white solid precipitated that was filtered off, washed with chloroform and crystallized in tetrahydrofuran, m.p. $249-51{ }^{\circ} \mathrm{C}$.

NMR Experiments. The ${ }^{1} \mathrm{H}(400.13 \mathrm{MHz}),{ }^{13} \mathrm{C}(100.62 \mathrm{MHz})$ and ${ }^{15} \mathrm{~N}(40.56 \mathrm{MHz})$ spectra in solution were obtained with a Bruker DRX-400 instrument at $300 \mathrm{~K}$. Chemical shifts ( $\delta$ in ppm) are given with reference to internal solvent DMSO- $d_{6}$ (2.49 for ${ }^{1} \mathrm{H}$ NMR and 39.5 for ${ }^{13} \mathrm{C}$ NMR) and from external nitromethane for ${ }^{15} \mathrm{~N}$ NMR; the spectra done in TFAA solution were recorded 
with a lock capillary with DMSO- $d_{6}$. Typical parameters for ${ }^{1} \mathrm{H}$ NMR spectra were the spectral width $5000 \mathrm{~Hz}$, pulse width $7.5 \mu$ s at an attenuation level of $0 \mathrm{~dB}$ and resolution $0.27 \mathrm{~Hz}$ per point. Typical parameters for ${ }^{13} \mathrm{C}$ NMR spectra were the spectral width $20500 \mathrm{~Hz}$, pulse width $10.6 \mu \mathrm{s}$ at an attenuation level of $-6 \mathrm{~dB}$ and resolution $0.63 \mathrm{~Hz}$ per point; WALTZ-16 was used for broadband proton decoupling; the FIDS were multiplied by an exponential weighting $(\mathrm{lb}=1$ $\mathrm{Hz}$ ) before Fourier transformation. 2D inverse proton detected heteronuclear shift correlation spectra, ${ }^{1} \mathrm{H}_{-}{ }^{13} \mathrm{C}$ gs-HMQC and ${ }^{1} \mathrm{H}_{-}{ }^{15} \mathrm{~N}-\mathrm{HMBC}$ were carried out with the standard pulse sequences. Solid state ${ }^{13} \mathrm{C}(100.73 \mathrm{MHz})$ and ${ }^{15} \mathrm{~N}(40.60 \mathrm{MHz})$ CPMAS NMR spectra have been obtained on a Bruker WB 400 spectrometer at $300 \mathrm{~K}$ using a $4 \mathrm{~mm}$ DVT probehead and a 4-mm diameter cylindrical zirconia rotor with Kel-F end-caps. The ${ }^{13} \mathrm{C}$ and ${ }^{15} \mathrm{~N}$ spectra are given with reference to external $\mathrm{Me}_{4} \mathrm{Si}$ and nitromethane, respectively.

Computational details. The geometry of the molecules has been optimized at the B3LYP/6$31 \mathrm{G}^{* * 7,8}$ computational level within the Spartan 02 package. ${ }^{9}$ The minimum nature of the structures has been confirmed by frequency calculation at the same computational level.

$\mathrm{X}$-Ray data collection and structure refinement. Pale yellow thin plate single crystals of $\mathrm{C}_{13} \mathrm{H}_{10} \mathrm{~N}_{4} \cdot \mathrm{H}_{2} \mathrm{O}$ 1b suitable for X-ray diffraction experiments were prepared by crystallization from water. Data collection was carried out at room temperature on a Bruker Smart CCD diffractometer using graphite-monochromated Mo-K $\alpha$ radiation $(\lambda=0.71073 \AA$ ) operating at 50 $\mathrm{kV}$ and $30 \mathrm{~mA}$. The data were collected over a hemisphere of the reciprocal space by combination of three exposure sets. Each exposure time was of 30 s covering $0.3^{\circ}$ in $\omega$. The first 100 frames were recollected at the end of the data collection to monitor crystal decay, and no appreciable drop in the standard reflections intensities was observed. The cell parameters were determined and refined by least-squares fit of all reflections. Most of the calculations were carried out with the Smart software for data collection and reduction.

A summary of the fundamental crystal and refinement data of $\mathbf{1 b}$ is given in Table 4. The structure was solved by direct methods and refined employing full-matrix least-squares with $\left(\right.$ SHELXTL-97) ${ }^{10}$ refining on $\mathrm{F}^{2}$. Anisotropic parameters were used in the last cycles of refinement for all non-hydrogen atoms. Hydrogen atoms bonded to the oxygen atoms have been located in a Fourier synthesis, included and refined as riding on their respective oxygen atoms. The remaining hydrogen atoms were included in calculated positions and refined as riding on their respective carbon atoms and the thermal parameters related to the bonded atoms. Final $\mathrm{R}(\mathrm{Rw})$ values were $0.0447(0.1299)$. The supplementary crystallographic data have been passed to the Cambridge Crystallographic Data Centre (CCDC deposition number 705640). These data can be obtained free of charge from the CCDC via www.ccdc.cam.ac.uk/data request/cif. 
Table 4. Crystal and refinement data for 4-(E)-[1H-benzimidazol-1-ylimino) methyl] pyridin-3ol (1b)

\begin{tabular}{ll}
\hline Crystal data & $\mathbf{1 b}$ \\
\hline Empirical formula & $\mathrm{C}_{13} \mathrm{H}_{10} \mathrm{~N}_{4} \cdot \mathrm{H}_{2} \mathrm{O}$ \\
Formula weight & 256.27 \\
Crystal system & Monoclinic \\
Space group & $P 2_{1} / n$ \\
$a(\AA)$ & $13.254(2)$ \\
$b(\AA)$ & $5.460(2)$ \\
$c(\AA)$ & $17.546(2)$ \\
$\beta\left({ }^{\circ}\right)$ & $94.153(2)$ \\
$V\left(\AA^{3}\right)$ & $1266.3(2)$ \\
$Z$ & 4 \\
$F(000)$ & 536 \\
$\rho_{\text {calc. }}\left(\mathrm{g}^{-1}{ }^{-3}\right)$ & 1.344 \\
$\left.\mu(\mathrm{mm})^{-1}\right)$ & 0.095 \\
Scan technique & $\omega$ and $\varphi$ \\
Data collected & $(-15,-6,-20)$ to $(15,6,17)$ \\
$\theta$ range $\left({ }^{\circ}\right)$ & $1.86-25$ \\
Reflections collected & 9140 \\
Independent reflections & $2228\left(R_{\text {int }}=0.0831\right)$ \\
Completeness to maximum $\theta$ & $100 \%$ \\
Data/restraints/parameters & $2228 / 0 / 182$ \\
GOF $\left(F^{2}\right)$ & 1.029 \\
$R^{\mathrm{a}}[I>2 \sigma(I)]$ & $0.0456(1239$ ref. observed) \\
$R w_{F}{ }^{\mathrm{b}}$ (all data) & 0.1328 \\
Largest residual peak $\left(\mathrm{e} \AA^{-3}\right)$ & 0.181 \\
\hline
\end{tabular}

${ }^{\mathrm{a}} \Sigma\left[\left|F_{\mathrm{o}}\right|-\left|F_{\mathrm{c}}\right|\right] / \Sigma\left|F_{\mathrm{o}}\right| \cdot{ }^{\mathrm{b}}\left\{\Sigma\left[w\left(F_{\mathrm{o}}{ }^{2}-F_{\mathrm{c}}\right)^{2}\right] / \Sigma\left[w\left(F_{\mathrm{o}}{ }^{2}\right)^{2}\right]\right\}^{1 / 2}$

\section{Acknowledgements}

This work was supported by DGES/MEyC (CTQ2007-62113) of Spain. One of us (A.P.) is indebted to the MCyT of Spain for an FPI grant.

\section{References}

1. Sanz, D.; Perona, A.; Claramunt, R. M.; Elguero, J. Tetrahedron 2005, 61, 145. 
2. Sanz, D.; Perona, A.; Claramunt, R. M.; Pinilla, E.; Torres, M. R.; Elguero, J. Helv. Chim. Acta 2006, 89, 1290.

3. Perona, A.; Sanz, D.; Claramunt, R. M.; Elguero, J. Molecules 2006, 11, 453.

4. Perona, A.; Sanz, D.; Claramunt, R. M.; Pinilla, E.; Torres, M. R.; Elguero, J. J. Phys. Org. Chem. 2007, 20, 610.

5. Perona, A.; Sanz, D.; Claramunt, R. M.; Elguero, J. Magn. Reson. Chem. 2008, 46, 930.

6. R. M. Claramunt, D. Sanz, J. Catalán, F. Fabero, N. A. Garcia, C. Foces-Foces, A. L. Llamas-Saiz, J. Elguero, J. Chem. Soc. Perkin Trans. 2 1993, 1687.

7. Becke, A. D. J. Chem. Phys. 1993, 98, 5648; Lee, C.; Yang, W.; Parr, R. G. Phys. Rev. B 1988, 37, 785; Becke, A. D. Phys. Rev. A 1988, 38, 3098; Miehlich, B.; Savin, A.; Stoll, H.; Preuss, H. Chem. Phys. Lett. 1989, 157, 200.

8. Hariharan, P. A.: Pople, J. A. Theor. Chim. Acta 1973, 28, 213.

9. Spartan '02 for Windows from Wavefunction Inc.

10. Sheldrick, G. M. SHELX97, Programs for Crystal Structure Analysis, release 97-2; University of Gottingen: Göttingen, Germany, 1998. 